\title{
PENGARUH BIMBINGAN SOSIAL DAN MOTIVASI TERHADAP KEDISIPLINAN BELAJAR SISWA KELAS VIII SMP NEGERI 4 MAGETAN TAHUN PELAJARAN 2011-2012
}

\author{
Vitalis Djarot Sumarwoto
}

\begin{abstract}
Abstrak
Faktor kedisiplinan siswa di sekolah merupakan unsur yang tidak dapat diabaikan. Perilaku disiplin bagi seorang pelajar merupakan bagian integral dalam pencapaian tujuan pendidikan dan pembelajaran di sekolah. Tinggi-rendahnya kedisiplinan siswa di sekolah antara lain akan mempengaruhi optimal-tidaknya motivasi belajar siswa dalam mengikuti proses pembelajaran di sekolah. Secara psikologis dapat dinyatakan bahwa siswa kurang disiplin dalam berperilaku dalam kehidupan, dalam aktivitas belajarnya di sekolah, maka akan berpengaruh terhadap motivasi belajarnya, sehingga akan berpengaruh terhadap daya-daya jiwa lain yang dimiliki siswa. Penanggulangan terhadap kecenderungan masalah siswa tersebut antara lain layanan bimbingan sosial, karena hakikat bimbingan sosial adalah membantu siswa yang mengalami masalahmasalah sosial, yang dapat mempengaruhi perilaku siswa.

Penelitian ini pada hakikatnya ingin mengetahui pengaruh bimbingan sosial dan motivasi belajar terhadap kedisiplinan belajar siswa kelas VII SMP Negeri 4 Maospati Magetan tahun pelajaran 2011-2012. Penelitian ini menggunakan metode ex-posfacto, karena pada dasarnya peneliti ingin menguji teori yang menyatakan bahwa faktor bimbingan sosial dan motivasi belajar akan mempengaruhi kedisiplinan belajar siswa. Untuk megetahui pengaruh antar variabel penelitin peneliti mengungkap data tentang keefektifan bimbingan sosial, motivasi belajar dan kedisiplinan belajar siswa di sekolah dengan teknik angket Penelitian ini melibatkan sampel sebanyak 50 siswa dari 179 anggota populasi, yang ditetapkan dengan teknik random sampling. Analisis data dalam penelitian ini menggunakan jasa statistik dengan rumus bangun Analisis Regresi: dua Prediktor.

Hasil uji hipotesis menyatakan bahwa harga F-hitung lebih besar dibanding Ftabel $(57,198>3,20=\mathrm{TS} / 5 \%)$. Jadi ada pengaruh yang signifikan bimbingan sosial dan motivasi belajar terhadap kedisiplinan belajar siswa kelas VII SMP Negeri 4 Maospati Magetan tahun pelajaran 2011-2012.
\end{abstract}

Kata Kunci: Bimbingan Sosial, Motivasi Belajar, dan Kedisiplinan Belajar

\section{Pendahuluan}

Hasil observasi peneliti pada siswa kelas VII SMP Negeri 4 Maospati Magetan selama Minggu kedua sampai ketiga pada bulan Juli tahun 2012, diperoleh informasi 
sebesar $47 \%$ siswa bermasalah dalam aspek kedisiplinan. Informasi di atas didukung oleh beberapa wali siswa dan konselor sekolah, yang menyatakan kedisiplinan siswa sangat memprihatinkan, dan perlu segera dicarikan solusinya. Salah satu solusi yang peneliti yakini membawa dampak positif adalah melalui layanan bimbingan sosial dan peningkatan motivasi belajar siswa.

Shetzer and Stone (dalam Winkel dan Sri Hastuti, 2006: 29) berpendapat bahwa bimbingan adalah suatu proses menolong individu memahami atau mengenali dirinya sendiri dan sekitarnya.

Sirley A. Hamrin (dalam Ermanto, 1998: 62) menyatakan bahwa: Bimbingan adalah proses memberi bantuan kepada individu/siswa agar dapat mengenal dirinya sendiri sedalam-dalamnya. berikut.

A.J. Jones (dalam Vitalis, 2003: 63) mendefinisikan bimbingan adalah sebagai

"Guidance involves personal help given by someone, it is to assist a person to decide where he want to go, what he want to do, or how he can best accomplish his purpose, it assists him to solve problems that arise in this life".

Inti definisi bimbingan menurut Jones adalah: Bimbingan memberi pertolongan kepada seseorang dalam mengambil keputusan tentang kemana dia akan pergi, apa yang dia akan lakukan atau bagaimana cara yang sebaik-baiknya dalam mencapai tujuan, bimbingan membantunya dalam memecahkan masalah-masalah yang timbul dalam kehidupannya.

Pernyataan di atas pada prinsipnya menegaskan bahwa bimbingan diartikan sebagai proses bantuan membantu individu dengan cara memberi informasi sebanyakbanyaknya, sesuai dengan kebutuhan individu yang dibimbing, agar dapat mengenal diri dan lingkungannya sebaik-baiknya, sehingga dapat digunakan untuk mengambil keputusan untuk mempersiapkan masa depannya.

Bertolak dari beberapa difinisi dan pengertian tentang bimbingan maka dapat dirumuskan pengertian bimbingan sosial dari para pakar bimbingan sebagai berikut:

Dewa Ketut Sukardi (2002: 39) mengartikan bimbingan sosial adalah membantu individu (siswa) mengenal dan berhubungan dengan lingkungan sosial yang dilandasi budi pekerti luhur, tanggung jawab kemasyarakan dan kenegaraan. 
Winkel (1991:27) menegaskan bahwa hakikatnya bimbingan sosial adalah suatu proses bantuan yang diberikan oleh seorang konselor yang profesional kepada individu (siswa) dalam upaya membina hubungan kemanusiaan dengan sesama manusia dalam berbagai lingkungan atau pergaulan sosial.

Achmad Juntika Nurihsan dan Akur Sudianto (2005: 13) menyatakan bahwa inti dari bimbingan sosial ialah bantuan kepada para siswa dalam menghadapi dan memecahkan masalah-masalah sosial.

Bertolak dari beberapa pengertian di atas peneliti berpendapat bahwa bimbingan sosial dapat dimaknai sebagai proses bantuan yang diberikan oleh seorang konselor yang berwenang kepada individu (siswa) di sekolah dalam membina hubungan kemanusiaan yang sehat dan bertanggung jawab. Bimbingan sosial bisa diartikan sebagai bantuan yang diberikan kepada siswa di sekolah dalam menghadapi dan mengatasi berbagai masalah pergaulan dan proses belajar dan membantu siswa meningkatkan dorongan siswa dalam aktivitas belajarnya.

Winkel dan Sri Hastuti (2006: 123) memberikan penjelasan tujuan bimbingan sosial di sekolah adalah: (a) mengembangkan kemampuan siswa dalam menghadapi dan mengatasi masalah-masalah pribadi dalam kaitannya dengan pergaulan sosial secara bertanggung jawab, (b) menciptakan lingkungan interaksi pendidikan yang kondusif, (c) mengembangkan sistem pemahaman diri dan sikap positif, serta trampil dalam membina pergaulan sosial, (d) memantapkan pemahaman tentang kekuatan diri sendiri dan pengembangannya untuk kegiatan-kegiatan yang kreatif dan produktif, dalam peranannya sebagai individu guna mempersipakan kehidupan pada masa yang akan datang, (e) memantapkan kemampuan berkomunikasi yang sehat (positif), dan (f) memotivasi siswa untuk meningkatkan kedisiplinan dalam belajar, dengan dasar kelemahan yang dimilikinya.

Perihal motivasi, para ahli psikologi pendidikan menegaskan sebagai berikut:

Sumadi Suryabrata (2004: 70) menjelaskan pengertian motivasi perlu membahas tentang "motif", yaitu keadaan dalam pribadi orang (siswa) yang mendorong siswa melakukan aktivitas-aktivitas tertentu dalam upaya mencapai sesuatu tujuan". Motif bukan sesuatu hal yang dapat diamati, tetapi sesuatu yang dapat disimpulkan karena dapat disaksikan melalui aktivitas yang diakukan. 
Husaini dan M. Noor Hs. (dalam Vitalis, 2000: 28) mengartikan motif adalah suatu rangsangan, dorongan, atau pembangkit energi (tenaga) bagi terjadinya suatu tingkah laku".

Bertolak dari pengertian "motif” kemudian beberapa pakar psikologi pendidikan menyatakan sebagai berikut:

Winkel (dalam Vitalis, 2003: 28) menyatakan bahwa motivasi merupakan daya penggerak yang telah menjadi aktif. Motif menjadi aktif pada saat-saat tertentu apabila kebutuhan untuk mencapai suatu tujuan sangat dirasakan atau dihayati.

Wasty Sumanto (2003: 202) berpendapat bahwa motivasi adalah suatu proses dalam diri individu (siswa) yang membantu individu itu untuk menerangkan tingkah laku yang ditampakkan".

McDonald memberi definisikan motivasi adalah suatu perubahan tenaga di dalam diri seseorang yang ditandai oleh dorongan afektif dan reaksi-reaksi dalam mencapai tujuan (dalam Wasty Sumanto, 2003: 203).

Bertolak dari beberapa pengertian motivasi di atas, maka pada dasarnya motivasi adalah daya penggerak yang telah menjadi aktif pada saat-saat kebutuhan untuk mencapai tujuan sangat dirasakan atau dihayati. Motivasi dalam kehidupan siswa di sekolah dirasakan penting karena beberapa alasan sebagai berikut: (a) motivasi bermanfaat dalam memenuhi kebutuhan dan mencapai tujuan yang dikehendaki, (b) motivasi itu ditandai oleh dorongan afektif, (c) motivasi adalah sesuatu yang dapat dipelajari, dan (d) motivasi dapat digunakan secara bersamaan dan juga bergantian, khususnya dalam aktivitas belajar siswa (Ngalim Purwanto (2006: 116).

Motivasi belajar menurut Winkel (dalam Vitalis, 2002: 118) adalah keseluruhan daya penggerak dalam diri individu/siswa yang menimbulkan belajar, yang menjamin kelangsungan kegiatan belajar, dan memberi arah pada kegiatan belajar, sehingga tujuan yang dikehendaki oleh individu (siswa) dapat tercapai.

Ngalim Purwanto (2006) menyatakan motivasi belajar adalah daya penggerak dalam diri subyek, yang berupa energi, yang dibutuhkan subyek/siswa dalam aktivitas belajar.

Jadi hakikat motivasi belajar adalah suatu daya (kekuatan) dalam diri (siswa) yang melibatkan unsur kognitif dan afektif untuk memenuhi kebutuhan-kebutuhan 
pada saat siswa melakukan aktivitas belajar. Usaha tersebut oleh siswa perlu didukung antara lain oleh layanan bimbingan sosial, dan bisa berpengaruh terhadap kedisiplinan belajar, baik di rumah maupun di sekolah. Pernyataan ini memberi petunjuk bahwa fungsi utama motivasi belajar adalah sebagai berikut: (1) mendorong siswa untuk melakukan kegiatan belajar, (2) motivasi dapat memberi arah kegiatan yang tepat menuju tercapainya tujuan belajar, dan (3) berkat motivasi maka siswa memiliki kemampuan untuk memilih dan menyeleksi tingkah yang baik atau yang kuran baik. Perilaku yang dinilai baik atau berharga bagi hidup siswa akan diserap dan yang tidak berharga akan ditinggalkan (Gino, HJ, dan kawan-kawan (1994: 24). Oleh karena itu apabila siswa menilai bahwa layanan bimbingan sosial itu baik (berharga) maka siswa akan memanfaatkan dengan sebaik-baiknya, dengan didukung oleh kedisiplinan dalam mengikutinya.

Winkel (dalam Vitalis, 2002: 44) berpendapat motivasi belajar dibedakan menjadi dua, yaitu: motivasi intrinksik dan ekstrinksik. Motivasi intrinksik adalah dorongan yang berasal dari dalam diri subyek (siswa) yang dimanfaatkan untuk memenuhi kebutuhan diri atau pribadi siswa, yang antara lain adalah mendorong siswa untuk meningkatkan kedisiplinan diri dalam memanfaatkan layanan bimbingan sosial di sekolah. Motvasi ekstrinsik adalah dorongan yang berasal dari luar diri siswa, seperti siswa berperilaku disiplin karena dibatasi oleh norma-norma atau aturan-aturan sekolah, atau siswa mengikuti bimbingan sosial di sekolah karena dianjurkan oleh pihak yang berwenang di sekolah tersebut.

Berdasarkan uraian di atas, maka beberapa faktor seperti: kematangan psikologis, informasi, partisipasi aktif, dan sadar tujuan belajar memiliki peran penting dalam membentuk kedisiplinan siswa di sekolah.

Depdiknas (2005: 268) mengartikan "disiplin" adalah: tata tertib (di sekolah atau di kemiliteran), ketaatan; kepatuhan kepada peraturan (tata tertib). Disiplin adalah suatu kondisi yang merupakan perwujudan dari sikap mental dan perilaku seseorang (siswa), apabila ditinjau dari aspek kepatuhan dan ketaatan terhadap ketentuan .....!".

WJS. Poerwadarminta (1986:254): kata disiplin diartikan sebagai: latihan batin dan watak dengan maksud supaya segala perbuatannya selalu menaati tata tertib (di sekolah), taat pada peraturan dan tata tertib". Pengertian dari kamus ini rupa-rupanya 
mengkaitkan disiplin dengan "ketaatan atau kepatuhan" terhadap peraturan; kondisi yang merupakan perwujudan sikap mental dan perilaku dalam hubungannya dengan aspek kepatuhan dan ketaatan terhadap ketentuan yang berlaku”.

Dewa Ketut Sukardi (2002: 97) menyatakan bahwa kedisiplinan belajar adalah merupakan inisiatif pribadi yang tetap tumbuh subur jika didibina dengan efektif, dan akan hilang pada sistem pembinaan disiplin yang tidak efektif'.

Menurut Moh. Shochib (2000: 11) pelaksanaan kedisiplinan belajar siswa perlu dikaitkan dengan pola pendidikan dan/atau bimbingan di sekolah. Tujuan utamanya membantu siswa mengembangkan disiplin diri. Siswa sebaiknya menyadari bahwa disiplin diri dalam belajar perlu tetap dipelihara dan dihayati bila siswa menginginkan tujuan belajar yang dikehendaki tercapai. Siswa perlu menyadari bahwa kedisiplinan belajar sebaiknya menjadi sikap dalam kehidupan sehari-hari di sekolah.

Salah satu makna esensial kedisiplinan adalah mengundang para siswa untuk lebih mengaktifkan diri dengan nilai-nilai moral untuk memiliki dan mengembangkan dasar-dasar disiplin diri, atas dasar beberapa kriteria sebagai berikut: (a) patuh dan taat terhadap tata tertib yang berlaku di sekolah, (b) melaksanakan semua kewajiban siswa, dan (c) menghindari larangan-larangan yang ditentukan oleh pihak sekolah.

Beberapa kriteria yang menjadi tolok ukur dalam melakukan kedisiplinan belajar siswa di sekolah, dan dirasakan hasilnya apabila didukung oleh faktor-faktor (1) fisik (kesehatan) tubuh yang prima, (2) faktor psikis, seperti motivasi dalam hidup dan dalam belajar, dan (3) faktor sosial, yaitu pergaulan yang sehat dengan sesama manusia.

\section{Metode Penelitian}

Penelitian ini menggunakan metode ex-post-facto. Pengumpulan data dengan teknik daftar cocok dan angket.

1. Teknik daftar cocok untuk mengungkap data bimbingan belajar, dan disediakan pernyataan aebanyak 15 butir. Pernyataan siswa dalam daftar cocok diklasifikasikan sebagai berikut: (a) sangat efektif, dengan kode (SE), sskor 4, (b) efektif, dengan kode (EF), skor 3, (c) cukup efektif, dengan kode (CE), skor 2, dan 
(d) kurang efektif dengan kode (KE), skor 1 (Suharsimi Arikunto, dalam Vitalis: 2011). Kisi-kisi daftar cocok bimbingan sosial. dapat dilihat pada tabel berikut:

Tabel 1. Kisi-kisi Daftar Cocok Bimbingan Sosial

\begin{tabular}{|c|l|c|c|}
\hline $\begin{array}{c}\text { No } \\
\text { Urt }\end{array}$ & \multicolumn{1}{|c|}{ Indikator Item } & $\begin{array}{c}\text { Distribusi } \\
\text { Item }\end{array}$ & $\begin{array}{c}\Sigma \\
\text { Item }\end{array}$ \\
\hline 1 & Penilaian siswa terhadap bimbingan sosial & $1,2,3$, & 3 \\
\hline 2 & Penghayatan siswa tentang materi bimbingan sosial & $4,5,6$ & 3 \\
\hline 3 & $\begin{array}{l}\text { Kemampuan siswa mengatasi masalah belajar setelah } \\
\text { mengikuti bimbingan sosial . }\end{array}$ & $7,8,9$ & 3 \\
\hline 4 & $\begin{array}{l}\text { Sikap siswa dalam menerima bantuan melalui } \\
\text { kegiatan bimbingan sosial }\end{array}$ & $10,11,12$ & 3 \\
\hline 5 & $\begin{array}{l}\text { Kemampuan mengambil keputusan bagi dirinya } \\
\text { setelah memperoleh informasi tentang bimbingan } \\
\text { sosial }\end{array}$ & $13,14,15$ & 3 \\
\hline & \multicolumn{1}{|c|}{ Total Item: } & & 15 \\
\hline
\end{tabular}

2. Teknik angket untuk memperoleh data tentang motivasi dan kedisiplinan belajar siswa. Angket penelitian disusun dalam bentuk pilihan ganda, dengan empat altenatif jawaban, yaitu: A (Selalu): Skor 4, B (Sering: Skor 3, C (Kadang-kadang: Skor 2, dan D (Tidak pernah): Skor 1 (lihat tabel 2).

Tabel 2. Distribusi Skor Untuk Pernyataan Angket

\begin{tabular}{|c|c|c|c|c|}
\hline Jawaban & Selalu & Sering & Kadang-kadang & Tidak pernah \\
\hline Skor & 4 & 3 & 2 & 1 \\
\hline
\end{tabular}

Item angket motivasi dan kedisiplinan belajar, masing-masing disediakan 15 butir. Kisi-kisi angket motivasi belajar (lihat tabel 3). Kisi-kisi angket kedisiplinan belajar (lihat tabel 4).

Tabel 3. Kisi-kisi Angket Motivasi Belajar

\begin{tabular}{|c|l|c|c|}
\hline $\begin{array}{c}\text { No } \\
\text { Urt }\end{array}$ & \multicolumn{1}{|c|}{ Indikator Item } & $\begin{array}{c}\text { Distribusi } \\
\text { Item }\end{array}$ & $\begin{array}{c}\Sigma \\
\text { Item }\end{array}$ \\
\hline 1 & Dorongan internal dalam aktivitas belajar & $1,2,3,4$ & 4 \\
\hline 2 & Dorongan eksternal dalam aktivitas belajar & $5,6,7,8$ & 4 \\
\hline 3 & Semangat belajar bersama dengan teman-teman & $9,10,1,12$ & 4 \\
\hline 4 & Menggunakan energi untuk persiapan belajar & $13,14,15$ & 3 \\
\hline & Total Item: & & 15 \\
\hline
\end{tabular}


Tabel 4. Kisi-kisi Angket Tentang Kedisiplinan Belajar

\begin{tabular}{|c|l|r|c|}
\hline No & \multicolumn{1}{|c|}{ Indikator Item } & Nomor Item & $\begin{array}{c}\Sigma \\
\text { Item }\end{array}$ \\
\hline 1 & Datang ke sekolah tepat waktu & $1,2,3$ & 3 \\
\hline 2 & Meninggalkan sekolah dengan ijin & $4,5,6$ & 3 \\
\hline 3 & Mengerjakan tugas guru sesuai jadwal & $7,8,9$, & 3 \\
\hline 4 & Menaati tata tertib di sekolah & $10,11,12$ & 3 \\
\hline 5 & $\begin{array}{l}\text { Mengikuti peraturan sekolah dengan penuh } \\
\text { kesadaran }\end{array}$ & $13,14,15$ & 3 \\
\hline & \multicolumn{2}{|c|}{ Total Item: } & 15 \\
\hline
\end{tabular}

Pelaksanaan pengumpulan data dilakukan pada minggu keempat bulan Juli tahun 2012, dengan dibantu oleh konselor sekolah tempat penelitian. Tempat penelitian di SMP Negeri 4 Maospati Kabupaten Magetan tahun pelajaran 2011-2012, yang berlamat di Jalan Mayor Jendral Sungkono Nomor 70 Magetan.

\section{Hasil Analisis Data Penelitian}

\section{Deskripsi Data}

a. Deskripsi Data Bimbingan Sosial $\left(\mathrm{X}_{1}\right)$

Berdasarkan skor bimbingan sosial, dengan $\mathrm{N}=50$ siswa, rentangan skor: 15-60, diperoleh hasil perhitungan: rerata $=42,74$, modus $=45$, median $=43,5$, $\mathrm{SD}=4,827$, skor maksimal $=53$, dan skor minimal $=34$.

Tabel 5. Distribusi Frekuensi Skor Bimbingan Sosial

\begin{tabular}{|c|c|c|}
\hline $\mathrm{I}$ & $\mathrm{Xi}$ & $\mathrm{f}$ \\
\hline $52-54$ & 53 & 2 \\
\hline $49-51$ & 50 & 2 \\
\hline $46-48$ & 47 & 12 \\
\hline $43-45$ & 44 & 10 \\
\hline $40-42$ & 41 & 10 \\
\hline $37-39$ & 38 & 7 \\
\hline $34-36$ & 35 & 7 \\
\hline Jumlah & -- & 50 \\
\hline
\end{tabular}


b. Deskripsi Data Motivasi Belajar $\left(\mathrm{X}_{2}\right)$

Berdasarkan penilaian angket bimbingan sosial dengan $\mathrm{N}=50$, rentangan skor: 15 - 60, diperoleh hasil perhitungan: mean $=44,94$, median $=45$, modus $=45, \mathrm{SD}=5,343$, skor maksimal $=57$, dan skor minimal $=36$.

Tabel 6. Distribusi Frekuensi Skor Angket Motivasi Belajar

\begin{tabular}{|c|c|c|}
\hline I & Xi & f \\
\hline $56-58$ & 57 & 1 \\
\hline $53-55$ & 54 & 2 \\
\hline $50-42$ & 51 & 8 \\
\hline $47-49$ & 48 & 6 \\
\hline $44-46$ & 45 & 15 \\
\hline $41-43$ & 32 & 7 \\
\hline $38-40$ & 39 & 7 \\
\hline $35-37$ & 36 & 4 \\
\hline Jumlah & -- & 50 \\
\hline
\end{tabular}

c. Deskripsi Data Hasil Isian Angket Kedisiplinan Belajar Siswa (Y)

Berdasarkan hasil angket kedisiplinan belajar dengan $\mathrm{N}=50$, rentangan skor 15 - 60, diperoleh perhitungan: mean $=49,86$, modus $=55$, mode $=50$, $\mathrm{SD})=6,433$, Skor maksimal $=59$, Skor minimal $=39$.

Tabel 7. Distribusi Frekuensi Skor Hasil Daftar Cocok

\begin{tabular}{|c|c|c|}
\hline $\mathrm{I}$ & $\mathrm{Xi}$ & $\mathrm{f}$ \\
\hline $57-59$ & 58 & 8 \\
\hline $54-56$ & 55 & 12 \\
\hline $51-53$ & 52 & 3 \\
\hline $48-50$ & 49 & 8 \\
\hline $45-47$ & 46 & 7 \\
\hline $42-44$ & 43 & 4 \\
\hline
\end{tabular}




\begin{tabular}{|c|c|c|}
\hline $39-41$ & 40 & 8 \\
\hline Jumlah & -- & 50 \\
\hline
\end{tabular}

\section{Hasil Penelitian Dan Uji Hipotesis}

Hasil analisis data pengaruh bimbingan sosial $\left(\mathrm{X}_{1}\right)$ dan motivasi belajar $\left(\mathrm{X}_{2}\right)$ terhadap kedisiplinan belajar (Y) tahun pelajaran 2011-2012 menunjukkan bahwa harga F-hitung $=57,198$. Setelah dikonsultasikan dengan r-tabel, dengan $\mathrm{N}=50$ dan derajad bebas (d.b) $=1$ adalah 3,20/TS=5\%. Jadi harga F-hitung lebih besar dibandingkan harga F-tabel $(57,198>3,20)$. Hasil tersebut menunjukkan pengaruh yang signifikan (Hasil perhitungan lihat lampiran)

Bertolak dari hasil analisis data, maka hipotesis penelitian, yang berbunyi ada pengaruh bimbingan sosial dan motivasi belajar terhadap kedisipinan belajar siswa kelas VIII SMP Negeri 4 Magetan tahun pelajaran 2010-2011, harus diterima.

Simpulan penelitian adalah "ada pengaruh bimbingan sosial dan motivasi belajar terhadap kedisipinan belajar siswa kelas VIII SMP Negeri 4 Magetan tahun pelajaran 2010-2011”. 
Lampiran

Tabel Persiapan Untuk Menghitung Pengaruh $\mathrm{X}_{1}$ dan $\mathrm{X}_{2}$ terhadap $\mathrm{Y}$ dengan Rumus Regresi: Dua Prediktor

\begin{tabular}{|c|c|c|c|c|c|c|c|c|c|}
\hline $\begin{array}{l}\text { No. } \\
\text { Urt }\end{array}$ & $\mathrm{X}_{1}$ & $X_{2}$ & $\mathrm{Y}$ & $\mathrm{X}_{1}^{2}$ & $\mathrm{X}_{2}^{2}$ & $\mathrm{Y}^{2}$ & $\mathrm{X}_{1} \mathrm{X}_{2}$ & $\mathrm{X}_{1} \mathrm{Y}$ & $\mathrm{X}_{2} \mathrm{Y}$ \\
\hline 01 & 35 & 36 & 40 & 1225 & 1296 & 1600 & 1260 & 1400 & 1440 \\
\hline 02 & 45 & 45 & 47 & 2025 & 2025 & 2209 & 2025 & 2115 & 2115 \\
\hline 03 & 42 & 44 & 58 & 1764 & 1936 & 3364 & 1848 & 2436 & 2552 \\
\hline 04 & 41 & 42 & 55 & 1681 & 1764 & 3025 & 1722 & 2255 & 2310 \\
\hline 05 & 45 & 46 & 56 & 2025 & 2116 & 3136 & 2070 & 2520 & 2576 \\
\hline 06 & 38 & 40 & 42 & 1444 & 1600 & 1764 & 1520 & 1596 & 1680 \\
\hline 07 & 37 & 38 & 40 & 1369 & 1444 & 1600 & 1406 & 1480 & 1520 \\
\hline 08 & 42 & 42 & 50 & 1764 & 1764 & 2500 & 1764 & 2100 & 2100 \\
\hline 09 & 41 & 44 & 51 & 1681 & 1936 & 2601 & 1804 & 2091 & 2244 \\
\hline 10 & 44 & 45 & 55 & 1936 & 2025 & 3025 & 1980 & 2420 & 2475 \\
\hline 11 & 36 & 39 & 40 & 1296 & 1521 & 1600 & 1404 & 1440 & 1560 \\
\hline 12 & 35 & 36 & 40 & 1225 & 1296 & 1600 & 1260 & 1400 & 1440 \\
\hline 13 & 36 & 42 & 44 & 1296 & 1764 & 1936 & 1521 & 1584 & 1848 \\
\hline 14 & 50 & 52 & 45 & 2500 & 2704 & 3025 & 2600 & 2750 & 2860 \\
\hline 15 & 45 & 55 & 56 & 2025 & 3025 & 3136 & 2475 & 2520 & 3080 \\
\hline 16 & 48 & 49 & 58 & 2304 & 2401 & 3364 & 2352 & 2784 & 2842 \\
\hline 17 & 45 & 45 & 55 & 2025 & 2025 & 3025 & 2025 & 2475 & 2475 \\
\hline 18 & 38 & 40 & 50 & 1444 & 1600 & 2500 & 1520 & 1900 & 2000 \\
\hline 19 & 46 & 46 & 47 & 2116 & 2116 & 2209 & 2116 & 2162 & 2162 \\
\hline 20 & 48 & 48 & 49 & 2304 & 2304 & 2401 & 2304 & 2352 & 2352 \\
\hline 21 & 35 & 38 & 40 & 1225 & 1444 & 1600 & 1330 & 1400 & 1520 \\
\hline 22 & 47 & 49 & 50 & 2209 & 2401 & 2500 & 2303 & 2350 & 2450 \\
\hline 23 & 40 & 49 & 51 & 1600 & 1936 & 2601 & 1760 & 2040 & 2244 \\
\hline 24 & 38 & 44 & 55 & 1444 & 1444 & 3025 & 1444 & 2090 & 2090 \\
\hline 25 & 40 & 38 & 46 & 1600 & 1681 & 2116 & 1640 & 1840 & 1886 \\
\hline 26 & 41 & 41 & 42 & 1681 & 1681 & 1764 & 1681 & 1722 & 1722 \\
\hline 27 & 46 & 41 & 55 & 2116 & 2304 & 3025 & 2208 & 2530 & 2640 \\
\hline 28 & 53 & 48 & 58 & 2809 & 2500 & 3364 & 2650 & 3074 & 2900 \\
\hline 29 & 48 & 50 & 58 & 2304 & 2304 & 3364 & 2496 & 2784 & 3016 \\
\hline 30 & 44 & 52 & 47 & 1936 & 1936 & 2209 & 1980 & 2068 & 2115 \\
\hline 31 & 47 & 45 & 59 & 2209 & 2209 & 3184 & 2679 & 2773 & 3363 \\
\hline 32 & 40 & 41 & 40 & 1600 & 1681 & 1600 & 1640 & 1600 & 1640 \\
\hline 33 & 39 & 44 & 47 & 1521 & 1936 & 2209 & 1716 & 1833 & 2068 \\
\hline 34 & 38 & 45 & 46 & 1444 & 2025 & 2116 & 1710 & 1748 & 2070 \\
\hline 35 & 52 & 55 & 59 & 2704 & 3025 & 3481 & 2860 & 3038 & 3245 \\
\hline 36 & 43 & 44 & 45 & 1849 & 1936 & 2025 & 1892 & 1935 & 1980 \\
\hline 37 & 42 & 42 & 48 & 1764 & 1764 & 2304 & 1764 & 2016 & 2016 \\
\hline 38 & 44 & 51 & 55 & 1936 & 2601 & 3025 & 2244 & 2420 & 2805 \\
\hline 39 & 41 & 45 & 50 & 1681 & 2025 & 2500 & 1845 & 2050 & 2250 \\
\hline 40 & 46 & 48 & 52 & 2116 & 2304 & 2704 & 2208 & 2392 & 2496 \\
\hline 41 & 39 & 39 & 42 & 1521 & 1521 & 1764 & 1521 & 1638 & 1638 \\
\hline
\end{tabular}




\begin{tabular}{|r|r|r|r|r|r|r|r|r|r|}
\hline 42 & 44 & 44 & 48 & 1936 & 1936 & 2304 & 1936 & 2112 & 2112 \\
\hline 43 & 46 & 51 & 55 & 2116 & 2601 & 3025 & 2346 & 2530 & 2805 \\
\hline 44 & 47 & 52 & 58 & 2209 & 2704 & 2364 & 2444 & 2726 & 3016 \\
\hline 45 & 36 & 37 & 39 & 1296 & 1369 & 1521 & 1332 & 1404 & 1443 \\
\hline 46 & 34 & 36 & 41 & 1156 & 1296 & 1681 & 1224 & 1394 & 1476 \\
\hline 47 & 45 & 48 & 56 & 2025 & 2304 & 3136 & 2160 & 2520 & 2688 \\
\hline 48 & 46 & 46 & 49 & 2116 & 2116 & 2401 & 2116 & 2254 & 2254 \\
\hline 49 & 48 & 50 & 58 & 2304 & 2500 & 3364 & 2400 & 2784 & 2900 \\
\hline 50 & 51 & 52 & 56 & 2601 & 2704 & 3126 & 2652 & 2856 & 2912 \\
\hline$\sum$ & 2137 & 2247 & 2493 & 92477 & 102379 & 126329 & 97148 & 107731 & 113391 \\
\hline
\end{tabular}

\section{PERHITUNGAN}

Diketahui;

$$
\begin{aligned}
& \mathrm{N}=50 \\
& X_{2}=2.247 \\
& \sum \mathrm{Y}^{2}=126.329 \\
& \sum \mathrm{X}_{1} \mathrm{Y}=107.731 \\
& \sum \mathrm{X}_{1}=2137 \\
& \sum \mathrm{X}_{2}{ }^{2}=102.379 \\
& \sum X_{1} X_{2}=97.148 \\
& \sum X_{2} Y=113.391 \\
& \sum \mathrm{X}_{1}{ }^{2}=92.477 \\
& \sum \mathrm{Y}=2.493
\end{aligned}
$$

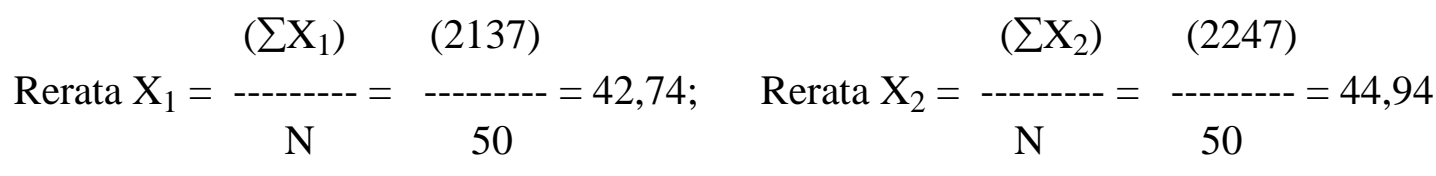

$$
\begin{aligned}
& \text { Rerata } \mathrm{Y}=\frac{\left(\sum \mathrm{Y}\right)}{\mathrm{N}}=\frac{(2493)}{--------}=49,86
\end{aligned}
$$

Berdfasarkan data yang tersedia pada tabel di atas, maka selanjutnya menghitung:
$\left(\sum \mathrm{X}_{1}\right)^{2}$
$(2137)^{2}$

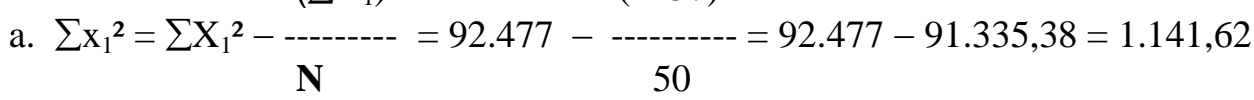
$\left(\sum \mathrm{X}_{2}\right)^{2} \quad(2247)^{2}$

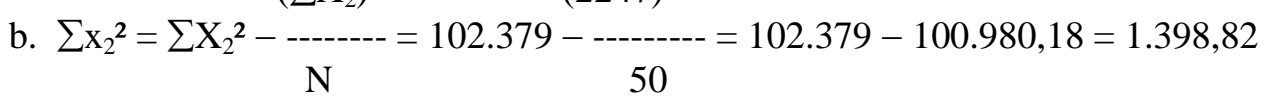
$\left(\sum \mathrm{Y}\right)^{2}$
$(2493)^{2}$

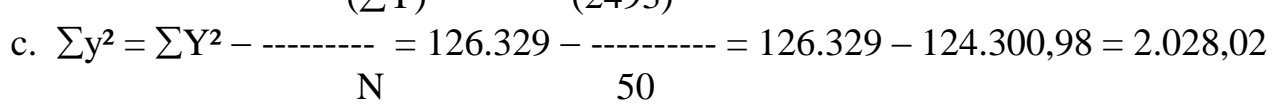

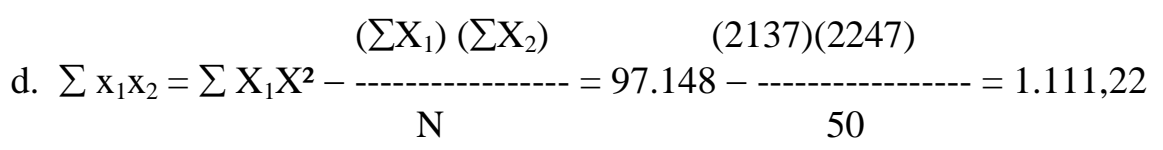




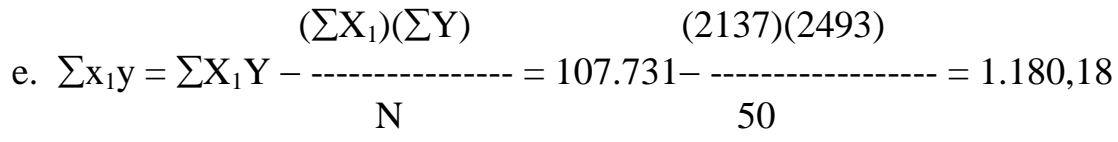

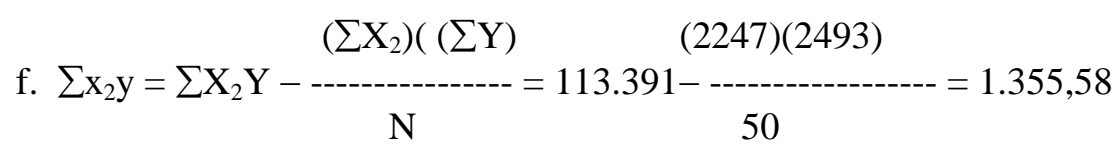

Persamaan simultan untuk mencari $\mathrm{a}_{1}$ dan $\mathrm{a}_{2}$ adalah sebagai berikut :

(1) $\sum \mathrm{x}_{1} \mathrm{y}=\mathrm{a}_{1} \sum \mathrm{x}_{1}^{2}+\mathrm{a}_{2} \sum \mathrm{x}_{1} \mathrm{x}_{2}$
(2) $\sum \mathrm{x}_{2} \mathrm{y}=\mathrm{a}_{1} \sum \mathrm{x}_{1} \mathrm{x}_{2}+\mathrm{a}_{2} \sum \mathrm{x}_{2}^{2}$

(2) $\sum x_{2} y=a_{1} \sum x_{1} x_{2}+a_{2} \sum x_{2}$
Diisikan dan dikerjakan:

(1): $1.180,18=1.141,62 \mathrm{a}_{1}+1.111,22 \mathrm{a}_{2}$

(2): $1.355,58=1.111,22 \mathrm{a}_{1}+1.398,82 \mathrm{a}_{2}$

(1): $1111,22=(3):(1,0621)=(1,0274) a_{1}+a_{2}$

(2): 1398,82 = (4): $(0,9691)=(0,7944) \mathrm{a}_{1}+\mathrm{a}_{2}-$

$$
\begin{aligned}
& (3)-(4):(5)=(0,093)=(0,233) a_{1} \\
& a_{1}=(0,093):(0,233)=0,399142 \\
& \text { (4): }(0,9691)=(0,7944)(0,399142)+a_{2} \\
& \left(0,9691=(0,31708)+a_{2}\right. \\
& \mathrm{a}_{2}=(0,9691)-(0,31708)=0,65202
\end{aligned}
$$

Koefisien korelasi antara kriterium $\mathrm{Y}$ dengan prediktor $\mathrm{x}_{1}$ dan prediktor $\mathrm{x}_{2}$ dihitung dengan rumus sebagai berikut:

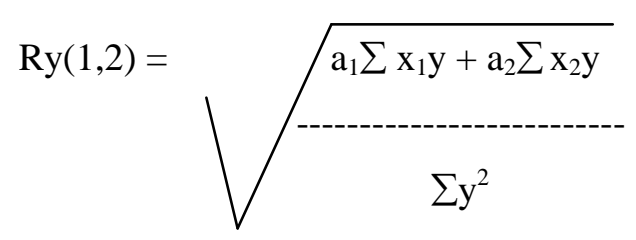

Keterangan:

$\operatorname{Ry}(1,2)$ : Koefisien korelasi antara $Y$ dengan $X_{1}$ dan $X_{2}$

$a_{1}$ : Koefisien prediktor $X_{1}$

$\mathrm{a}_{2}$ : Koefisien prediktor $\mathrm{X}_{2}$

$\sum \mathrm{x}_{1} \mathrm{y}:$ Jumlah produk antara $\mathrm{X}_{1}$ dengan $\mathrm{Y}$

$\sum \mathrm{x}_{2} \mathrm{y}$ : Jumlah produk antara $\mathrm{X}_{2}$ dengan $\mathrm{Y}$

(Sutrisno Hadi, 1990: 25). 


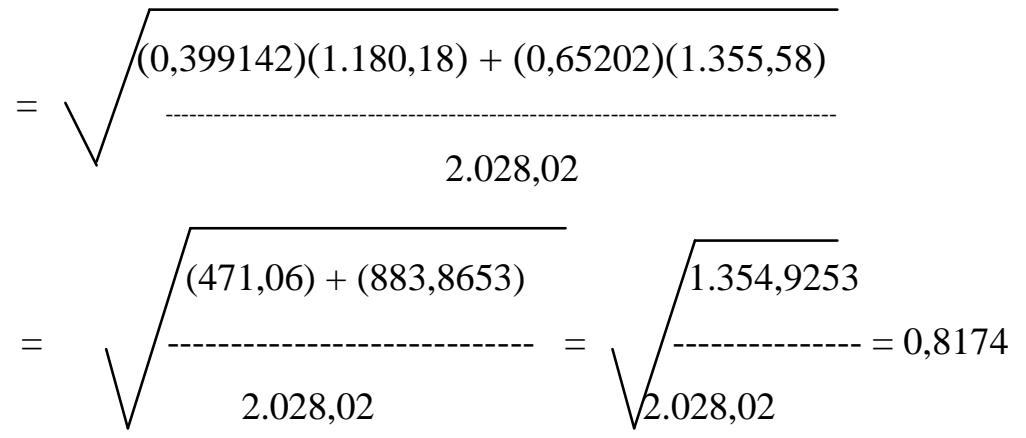

Jadi $\operatorname{Ry}(1,2)=0,8174$ (dikuadratkan untuk kepentingan analisis regresi). Dengan demikian $\mathrm{R}^{2}=0,668143$. Apakah hasil $\mathrm{Ry}(1,2)=0,8174$ itu signifikan atau tidak, maka perlu dihitung dengan menggunakan rumus F-regresi sebagai berikut:

$$
\begin{aligned}
& \mathrm{R}^{2}(\mathrm{~N}-\mathrm{m}-1) \\
& \text { Freg }= \\
& \mathrm{m}\left(1-\mathrm{R}^{2}\right)
\end{aligned}
$$

(Sumber: Sutrisno Hari, 1990: 26)

$$
\begin{array}{cc}
(0,668143)(50-2-1) & 31,403 \\
2(1-0,668143) & 0,663714
\end{array}
$$

Catatan: harga $\mathrm{F}-\mathrm{t} / \mathrm{TS}=5 \%$, dengan $\mathrm{db}=\mathrm{m}$ lawan $\mathrm{N}-\mathrm{m}-1$ atau 2 lawan $47=3,20$ 